\title{
Towards Building the Indigenisation Theory: The Zimbabwean Resource Management Perspective
}

\author{
Charles Mavhunga \\ Faculty of Commerce and Law, Zimbabwe Open University (ZOU), Harare Region, Zimbabwe
}

Copyright $(2018$ by authors, all rights reserved. Authors agree that this article remains permanently open access under the terms of the Creative Commons Attribution License 4.0 International License

\begin{abstract}
The dearth of studies to establish the line of fit for the indigenisation policy in Zimbabwe and the enactment of the Zimbabwe Democracy and Economic Recovery Act [S.494] [ZIDERA] ${ }^{1}$ by the United States of America [USA] to challenge the government of Zimbabwe's land reform and indigenisation policies motivated the production of this paper. Policy makers, members of the public, politicians, new farmers and other influential business pundits in Zimbabwe participated in the study. The study used non-experimental descriptive research design combining the deductive and inductive research approaches to be comprehensive. A desk review of secondary sources such as the indigenization Act [Chapter: $14: 33]^{2}$, publications, policy guidelines and other relevant material was sought to establish the theoretical proposition. Questionnaires and interviews were the main research instruments. The study findings were that developing countries were getting impoverished whilst developed countries were getting enriched by the way poor states got integrated into the world system. The basis of this result is that poor countries depend on exports of primary products whilst rich nations export processed goods to poor countries at exorbitant prices, thereby deepening the poverty level. This violates the United Nations General Assembly resolution [1803.[xvii] ${ }^{3}$ which entrenches the Principle of Permanent Sovereignty over Natural Resources.(PPSNR). To correct the imbalance, the study conclusion supports the need to indigenize the economy, but with a policy shift on the modalities in the configuration of the policy framework. The study also recommends the adoption of the Line of Fit theory in which indigenisation policy consideration focuses mainly on product beneficiation than continual exports of primary products. This indigenisation model need to embrace a 360 model which embraces mainly indigenized education systems, indigenized economic models, indigenized financial and management literacy and an indigenized corporate governance policy document for Zimbabweans and the removal of sanctions by the United States of America to give a chance to Zimbabweans to grow the economy to a 100 billion mark by 2030 .
\end{abstract}

Keywords Indigenization Policy, Natural Resources, Sanctions, New Farmers

\section{Introduction}

The injustice of ninety years of colonial rule [1890 to 1980] the penurious situation of the majority of Zimbabweans and the racially skewed colonial laws forced the Government of Zimbabwe to enact the indigenisation policy in the country [Chowa,2013 ${ }^{4}$,Murombo, 2010] $]^{5}$.In the colonial period, Floyd,[1959:22] $]^{6}$ holds that indigenous people were moved from arable lands by force and by skewed legal systems to give supremacy to White settlers in crop and animal production and access to lucrative markets. In the same vein, Brinn, $[1987: 13]^{7}$ established that, land suitable for wild life in Wedza, with poor soils, bad land-scape, rocky faces and steep terrain and with low potential for mechanization and irrigation was allocated to black people.

According to Gaidzanwa, [1981:21] $]^{8}$, the creation of reserves was a mechanism to limit capital expansion for the indigenous farmers in the then Rhodesia now Zimbabwe. The major reason was to promote supply of labour for the White settlers. The majority of black Zimbabweans were disempowered to nullity for a period of ninety years [1890-1980].According to New African Special Report $[2013]^{9}$, the colonial powers used the following pieces of legislation to disempower the majority black Zimbabweans:

Charter of the British South African Company [BSAC] $^{10:}$ The legislation created the legitimate colonization of Zimbabwe and black people in the country lost ownership of the country leading to the beginning of disempowerment.

The Companies [Act No.47 of 1951] ${ }^{11}$ : The Act established stringent business registration requirements for indigenous black entrepreneurs but White entrepreneurs got highly relaxed registration status. 
The Factory [Act No 20 of 1948$]^{12}$ : The Act established highly stringent registration conditions for black owned factories and relaxed positions for white owned factories.

The Public Health [Act No.19 of 1924] [Chapter 328 ${ }^{13}$ : The Act was designed to protect the establishment of white businesses through relaxed standards for white owned companies and highly stringent conditions for black owned businesses, leading to harassment of black owned small businesses.

The Urban Councils and Regional Town and Country Planning [Act no. 22 of 1976]: ${ }^{14}$ The Act empowered the local Government to regulate the type, location and activities of black-owned businesses and offered an open cheque to white people to operate any type of businesses with no limitation. The Local Government was also empowered to demarcate certain areas to be for whites only such that blacks would be prosecuted if found moving around, thus limiting freedom of movement for black people.

The Food and Food standards [Act No.25 of 1971] $[\text { Chapter 321] }]^{15}$ : The Act established stringent registration conditions for black entrepreneurs and relaxed the requirements for the white people.

Second Hand and Goods [Act No 25 of 1956] [Chapter 293] ${ }^{16}$ : The Act prohibited the importation of second hand goods into the country. Blacks were affected as they had very low income.

The income tax Act No 5 of 1967 [Chapter $181]^{17}$ :The Act established a discriminatory tax system of which blacks were forced to pay the hut tax, dip tank tax and others whilst White people in the country would receive tax rebates and tax exemptions.

The land apportionment [Act of 1930] ${ }^{18}$ The Act empowered the Whites only government to move blacks from fertile lands to poor and reserved areas and allocate fertile soils to Whites only leaving the poor blacks getting languishing in poverty. The Act reduced black people to labourers in farms owned by Whites of which the white farmer would pay peanuts as wages [Whitelow, 1988:13 $]^{19}$.

\subsection{The Turning Point into Zimbabwe}

Zimbabweans engaged into a liberation struggle to fight the colonial system to free black people from the long and enduring suffering. In the struggle, black people paid a price in the form of blood-shade. Tens of thousands of people perished to remove the colonial system in Zimbabwe. The colonial government dropped bombs in Mozambique, Tanzania and Zambia where Zimbabweans had camped to receive military training. In Mozambique, bombs were dropped by the colonial powers in places such as Nyadzonia, Chimoio, and Tembwe and Zimbabweans died [Shamuyarira, 1981] ${ }^{8}$. War ended in 1980 and Zimbabwe got its independence. The new and democratic Government formed revised the various pieces of legislation which the colonial system was using to destroy the liberty of blacks to become empower the disadvantaged black people. According to Dr. Nathan Shamuyarira, $[1998]^{20}$ the liberation was fought to whip the colonial government to shift from left to right, implying that laws that empowered the colonial government to disempower blacks were repealed. In this light, the democratic black Government enacted the indigenisation and empowerment Act, [Chapter 14:33] $]^{2}$ to correct the imbalance created for more than ninety years between black indigenous and White people. The enactment of the Act was in alignment with the United Nations' resolution [1803[xvii] ${ }^{3}$ of 1962. The [Ministry of Youth, indigenisation and Empowerment, $2013]^{21}$

The United Nations is the birthplace of the indigenisation policy framework [Professor, Erica Irene,2003 $]^{22}$.The United Nations General Assembly resolution 1803 [xvii] of 1962 entrenched the Principle of Permanent Sovereignty over Natural Resources [PSNR] ${ }^{2}$ by declaring that it is the right of the people 's nation to have permanent sovereignty over their natural wealth and resources. The reasons for the adoption of the resolution were as follows:

- That indigenous people are colonized people in the economic, political and historical sense;

- That indigenous people suffer from unfair and unequal economic arrangements typically suffered by other colonized people;

- That the principle of permanent sovereignty over natural resources is necessary to level the economic and political playing field and to provide protection against unfair and oppressive arrangements;

- That indigenous people have a right to development and actively to participate in the realization of this right; sovereignty over their natural resources is an essential prerequisite for this; and

- That the natural resources originally belonged to the Indigenous people concerned and were not, in most situations, freely and fairly given up.

- That the inadequacy and unfairness in certain present legal regimes regarding bio-prospecting, patents, and other intellectual property laws have deprived Indigenous people of valuable economic resources and have resulted in damage to Indigenous cultures as well.

- The enactment of the Act was therefore a framework to involve Zimbabweans to participate in the mainstream activities of the country`s economy [Ministry of Youth, indigenisation and Empowerment, $2013]^{21}$.

According to Mbiti,[1992:36] $]^{23}$, God principally own and controls nature and the human being is the highest intellect to direct the universe towards its destiny. In the same vein,[Wright,1983:53] $]^{24}$ holds that the supply of natural resources is an Act of God for sustenance of life. It is therefore an abomination of the Act of God for man to 
fail to benefit from the gift of natural resources as per the designation of the almighty, [Masengwe, 2008] $]^{25}$.In this light, the indigenisation policy was therefore meant to unhook Zimbabweans from the endemic syndrome of dependence [Ministry of Youth, indigenisation and Empowerment, 2013 $]^{21}$. The government of Zimbabwe was convinced that the nation needed a level playing field to afford equal opportunities and unhindered access to resources and skills.

However, Magure,[2010] $]^{26}$ argues that the idea to indigenize the economy was right but the policy framework scares away foreign direct investments [FDI], and is a limitation to employment creation and economic growth,[Thouvenot, 2014] $]^{27}$. In this line of thinking Thouvenot further notes that investors are not willing to become minority shareholders. Bell, [2010]28 criticized the policy on the grounds that the policy violates property rights and must be observed in the context of reverse discrimination. The major threat of the indigenisation policy was the configuration of the 49/51 framework which became too theoretical to understand its implementation. The controversies and other supporting view points of the indigenisation policy framework motivated the need to establish a detailed theory towards the indigenisation of natural wealth in Zimbabwe in this research study.

\section{Objectives}

2.1. To establish a line of fit for the indigenisation policy in Zimbabwe.

2.2. To define the indigenisation best practice for Zimbabwe and other developing nations in Africa and the world at large.

\section{Materials and Methods}

The study used both qualitative and quantitative research design to collect information [Descombe, $2012]^{29}$. The qualitative approach enabled the researcher to interview participants, and data collected was systematically classified and coded to establish themes and patterns [Descombe 2012] $]^{29}$. Data collected through qualitative means helped the researcher to establish a deep understanding of specific issues which led to the enactment of the indigenisation policy and the resultant criticism of the Act afterwards, however, to remove the elements of subjectivity in the study, the researcher applied quantitative techniques to justify the results. Questionnaires were used to collect quantitative data from respondents,[Patton,2002] $]^{30}$.A sample frame of 44 participants from a target population of 50 was used in the study [Saunders, et al.2012] ${ }^{31}$ and judgmental sampling was applied to identify relevant and credible study participants,[Patton 2002$]^{30}$. The study carried out an ethical principle of confidentiality in which names of participants were not going to be for the public domain unless authorized to do so by the owner. It was also an ethical principle in the study not to disclose information publicly outside the confinement of this research paper,[Descombe, 2012 $]^{29}$.

\section{Results}

\subsection{Support for the Indigenisation Policy in Zimbabwe}

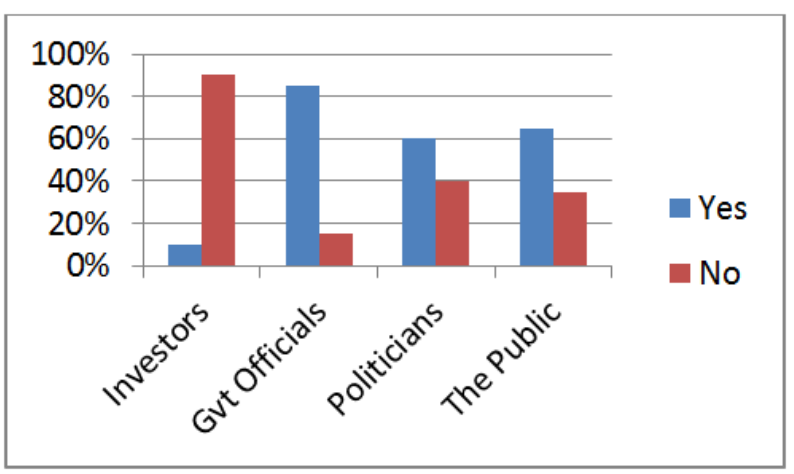

Figure 1. Level of support of indigenisation policy

The study results show that the majority of Investors [80\%] did not support the policy, but the government officials, politicians and the public in general showed greater support for the policy. The study results were consistent with the findings of Masengwe, $[2008]^{25}$ who established that the popularity of the indigenisation policy was by its very nature the Act of God who endowed natural resources for his people to benefit from them. The country must indigenize to generate wealth for the citizens [Fungati, $2014]^{32}$. Stiglitz, $[2007]^{33}$ confirms that countries such as Dubai, Kuwait, Egypt and other Arab countries are very rich because of oil resources. Norway escaped from poverty after an effective implementation of the indigenisation of oil resources for the benefit of the country,[Stiglitz, 2007] $]^{33}$.It is an abomination of the Act of God for man to fail to benefit from the gift of natural resources [Masengwe, 2008] ${ }^{25}$,however, Investors showed lack of support for the indigenisation policy possible due to the implementation of the policy framework. This result was consistent with the submissions made by the Zimbabwe Chamber of Mines, [2009 $]^{34}$ that the indigenization policy Act was a threat to the country's lines of credit in the mining sector, furthermore, Africa's highest ranking Archbishop in the Global Anglican community, Archbishop Desmond Tutu of South Africa and Dr. John Sentamu of Uganda in Bein Freith, [2011] $]^{35}$ have criticized the Government of Zimbabwe citing that the policy of indigenisation, especially, the land reform as causing both economic and social suffering of people in Zimbabwe. Dr. John Santam further argued that the policy of indigenization was racist and the family of "God must stop 
it”.

\subsection{Should Developing Countries Indigenize?}

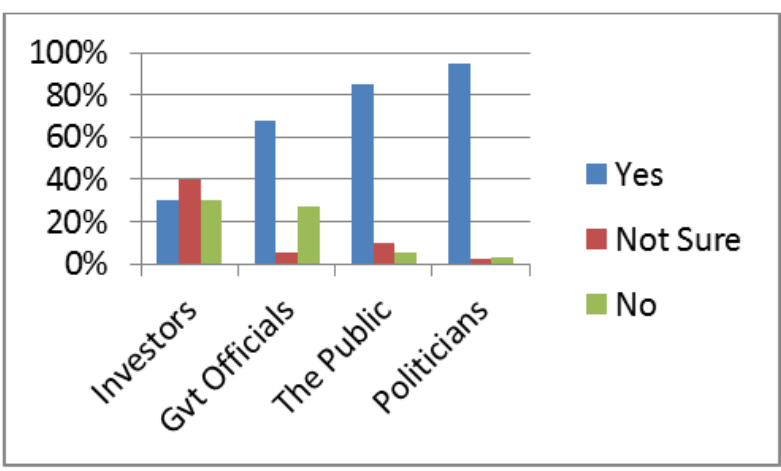

Figure 2. Should developing countries indigenize?

Figure 2 shows that politicians, the public and Government officials were in total support that developing countries such as Zimbabwe should indigenize their enonomies, but investors were skeptical about the views relating to the sense to indigenize economies. The result was consistent with Makwiramiti, [1999] ${ }^{36}$ who established that investors from the world community are failing to understand the indigenisation framework and its implementation configuration. In the same vein, Friedman, $[2002]^{37}$ also argues that investors need to understand the contribution of the indigenous people to correct the imbalance. Politicians, members of the public and the Government established support for the indigenisation policy possibly on the grounds of the dependence theory developed by Raul Prebisch ${ }^{38}$.The Dependency theory holds that resources flow from the periphery of the poor and underdeveloped states to a core of wealthy states, enriching the latter at the expense of the former. In this light, the dependency theory figures prominently in the debate over how poor countries can best be enriched or developed.

\subsection{Major Challenges to Implement Full Indigenisation in Zimbabwe}

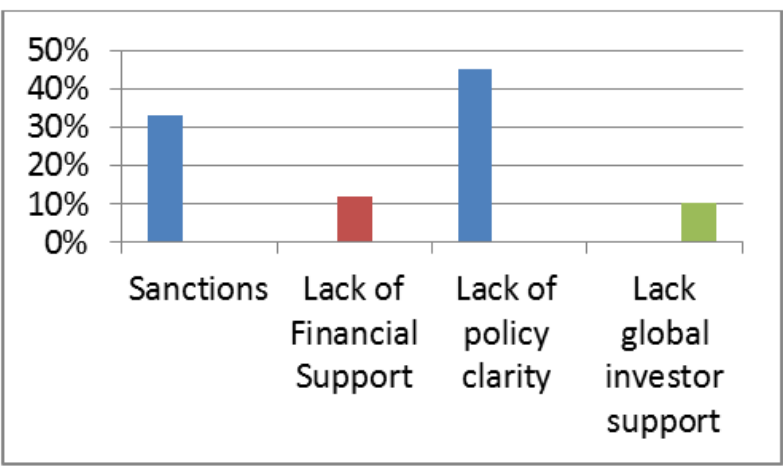

Figure 3. Major challenges of the indigenization policy implementation in Zimbabwe.
Figure 3 shows that the major challenge facing the indigenisation policy implementation in Zimbabwe was mainly lack of policy clarity, followed by Political Sanctions imposed by the United States of America, and then lack of investor support and finally financial support from the local indigenous people. This result was consistent with the views of Bauer, $[2015]^{39}$ who criticised indigenisation policies in developing countries because the internal markets for the poor countries were not large enough to support the economies of scale to keep prices low in the production processes. In the same vein, Mbeki,[2011 $]^{40}$ noted that third world countries shall continue to be in persistent poverty unless they align their policies to meet standards of developed countries. Developed countries are very cautious in resource usage; they import cheap raw materials and export expensive finished products draining the wealth status of the underdeveloped nations. Manwere, $(2013)^{41}$ established that sanctions have manifested themselves in the form of financial, trade, cultural and academic barriers, sports embargoes, diplomatic isolation, travel bans and the freezing of financial accounts of strategic entities and influential individuals in both politics and business limiting economic performance. Furthermore, Makwiramiti $[1999]^{36}$ holds that clarity on the $49 / 50$ Share ownership configuration was largely interpreted by investors to mean takeover of companies instead of economic participation hence the low support.

\section{Discussion}

The study results established the controversies associated with the indigenisation policies in Zimbabwe and other developing countries at large. The dominant result was that politicians, Government officials; the public supported the policy but investors showed a questioner mindset, however, basing on the views advanced by [Raul Prebisch $]^{38}$ about the dependency theory developed in the 1950 s, the indigenisation policy gained the support of the majority with the exception of investors who participated in the study. Raul Prebisch was the director of the United Nations Economic Commission for Latin America and established that the debate over how poor countries can best be enriched or developed remains incomprehensible. In this line of thinking Roy, $[1997]^{42}$ holds that the United Nations Statistics estimates that third world countries receive between 10 to 15 percent of their products. The majority of third world countries are debt ridden. Roy ${ }^{45}$ further notes that the third world countries are drained of 160 billion United States dollars per year in debt repayment and this becomes a vicious cycle unless drastic policy changes are made. The debt is induced through loans extended to third world countries to finance purchases from the developed countries to deepen the dependence syndrome. Further to that, Third world 
countries always lose ownership of their own products after processing. Chocolate is a product of Cocoa from Kenya, but Kenyans are getting peanuts in earnings from the export of the raw material than the final product. Nestle company, which is Headquartered in the United States is earning millions of dollars from chocolate sales, yet Kenya today is fifty times poorer than the United States, despite the country's resource base [Mbeki, 2011] $]^{40}$. The implication is that, if Kenya had indigenized cocoa processing, the country would have been somewhere in terms of development. Developing countries will continue to be in this route permanently until they master the strategy of rich countries. The dependency syndrome of developing countries must be explained in a 360 degree scale in terms of politics, economics, education, culture and other related policies Oslavalvo, [1969 $]^{44}$.

Developing countries are not getting a fair price on the resources that they possess to ensure that their dependency on Western models of survival will continue, [Mupepereki, $2016]^{45}$, furthermore, Africans, particularly Zimbabweans, have lost their opportunities in science, mathematics and innovations. African Science was more advanced than European Science, but we lost direction along the way, owing to the context in which colonization interpreted our culture, religion and social life. According to Professor, Mupepereki ${ }^{45}$, there was a lot of mathematics involved in the construction of Great Zimbabwe, and had it not been for colonization, Africans were very much advanced, but colonization destroyed the pillars of development and created a spirit of fear, which led to the dependency syndrome, and our economics in Africa is now explained in the Western context to be meaningful. We lost value, hence today, our Granite stone must be processed in Italy, or France and sold back to us as tiles, as if in Zimbabwe its taboo to have the processing machinery in our country, furthermore, Diamond from Marange in Mutare, Zimbabwe, must be certified for sale in Kimberely. Roy, $[1997]^{42}$ explains this phenomenon as the machinery of the developed countries to advance their cause and to remain rich. Developing countries will continue to get a lower value from their own resources, until they capture the economics of the world, and the strategy of the developing countries. Africans must indigenize their economics to stop the dependency syndrome [Mr. Fungati, Ministry of Youth, indigenisation and Empowerment, $2012]^{32}$. Zimbabweans need to capture the magic behind the indigenisation policy to escape from the melancholies of poverty, and to relinquish themselves from the challenges of the dependency syndrome currently affecting the majority of developing countries in Africa, however, Free market economists namely [Bauer and Wolf $]^{39}$, holds the view that developing countries may escape from poverty through multinational companies that globalize trade and transfer technology for the betterment of the developing country, but, the tacit knowledge about the technology is that latest technology is not transferred to the host country. Norberg, $[1997]^{46}$ established that
Multinational companies transfer second hand technology to protect their supremacy, and host countries will trail behind permanently in footings of competition and production of quality goods. Multinational companies have a mission to create a world of workers for developing countries, and it means the entire population in a developing country which is developed through the activities of multinational companies will be full of workers than visionaries. Wealth creation in the host country is meant for the country of origin than the host country. In terms of benefits, the country of origin's income is inform of dividend remittances and profit repatriation and the host country earn taxes, employment of its people for wages and salaries but in comparison, the country of origin earns more than ten times than the host country [Kirpalani, and Macintosh, 2012:66] ${ }^{47}$. Income from multinational companies is used to advance the economic status of the country of origin, and strengthen its pace of development and advances its course of knowledge through hiring good brains from the developing country in order to maintain the dependency syndrome. If developing countries would indigenize, and follow the route of developed countries and start hiring good brains from the world, they will start the march towards development and escape from poverty [Kirpalani and Macintosh, $2012]^{47}$. The study results were indicative that the majority supported the indigenisation policy issues but investors were on the middle of the road. What then is the policy consideration?

\section{Conclusions}

The study carries the conclusion that Zimbabwe need to march towards the indigenisation of the economy, but with a policy shift on the modalities in the configuration of the policy framework. The study recommends the adoption of the following Line of Fit theory to indigenize the economy:

\section{The indigenisation Line of fit Theory}

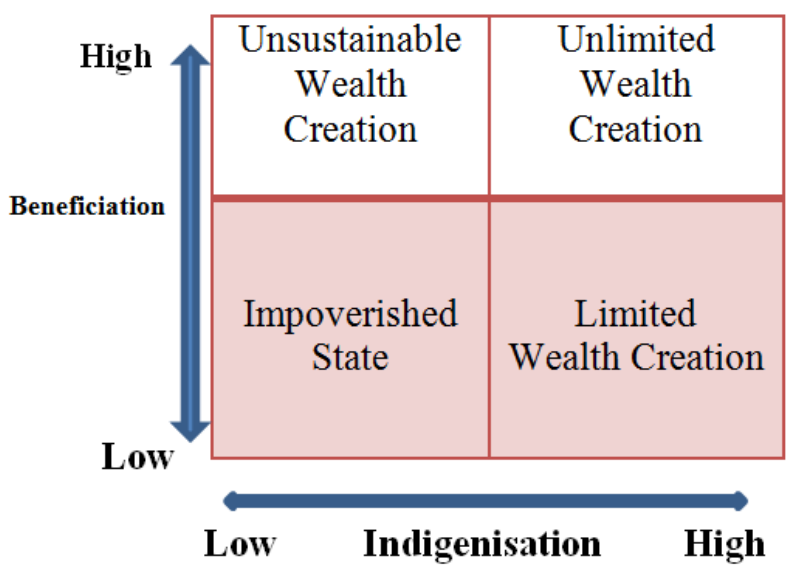

Source: Researcher`s own theory [2018] 
The indigenisation line of fit matrix shows that there is a strong relationship between indigenisation and product beneficiation in order to create wealth for developing nations.

Impoverished state: Low indigenisation which is backed by low Beneficiation leads to an impoverishment of the state. This is based on the assumption that when a country is run by foreigners, and locals are not participating in any form, the natural wealth of the economy is being impoverished. When indigenous people are not participating in the mainstream economic activities of the country, the national interest is lost, and wealth is lost. Further to that, more wealth is lost in that processing of raw material is done outside the country. Raw materials processed outside the country have other products that are contained in them such that the country of origin would be losing wealth. For an example, it is believed that raw coal contain more than seven other products, and raw groundnuts contain up to twenty-eight other products, so if processing of these products, the country of origin is losing wealth substantially. This notion is based on the dependency theory developed by Raul Prebisch [1950].The theory holds that resources flow from the periphery of the poor and underdeveloped states to a core of wealthy states, enriching the latter at the expense of the former. Poor countries are getting impoverished and rich ones getting enriched by the way poor states are integrated into the world system. Rich countries import raw materials from poor countries and the final product is sold to the poor country at a very high price draining all the resources of the poor. Indigenous people must take up the challenge and break grounds into scientific knowledge and develop theories and knowledge break through to produce own products that are indigenous in nature.

Limited Wealth Creation: High level of indigenisation which is supported by low level beneficiation, results in limited wealth creation. When a country has indigenized its activities, but excluding product beneficiation, the wealth creation status is on a limited scale. This is based on the notion that raw materials remain cheaper than finished products. Exports of raw material does not create high level wealth for the economy despite the fact that indigenous people are in full participation, and income is being retained in the country. Wealth is lost in than the raw material is a cheaper product. According to Mwaba, $[2008]^{53}$ Zambia's indigenisation policy failed because the concept was not embraced on a 360 degree scale in terms of economics, politics, education, financial literacy and other related micro and macro factors. The program was a nationalization of foreign industries but failed to embraces the value addition factor. This implies that value addition in the management of the indigenized companies, politics of the country, financial literacy, production processes. Africa is losing its wealth owing to lack of literacy in value addition processes (Mabwa, 2008) ${ }^{48}$. Where is the local participation in theories of development, new products development, new knowledge. Indgenous people must take up the challenge and get into the fray of deep research to discover and uncover wealth in their local areas for the benefit of people. This becomes the source of wealth which can be exported than the current status in which raw materials are getting exported. Zimbabwe is poor because it is exporting raw materials. The indigenous policy must therefore be shaped in this direction to stop exports of raw materials.

Unsustainable Wealth Creation: Low level of indigenisation which is supported by High level beneficiation results in unsustainable wealth creation. When foreign companies are largely involved in product beneficiation, the country's benefit is mainly employment creation for its people, tax on profits and other small payments derived from the company's activities. This is based on the views of Norberg, $[1997]^{46}$ who established that Multinational companies transfer second hand technology to protect their supremacy, and host countries will trail behind permanently in terms of competition and production of quality goods. Multinational companies are investment vehicles for their own countries of origin, and have a mission to create a world of workers for developing countries. In terms of benefits, the country of origin`s income is inform of dividend remittances and profit repatriation and the host country earn taxes, employment of its people for wages and salaries but in comparison, the country of origin earns more than ten times than the host country [Kirpalani, and Macintosh, 2012:66] ${ }^{47}$.Income from multinational companies is used to advance the economic status of the country of origin, and strengthen its pace of development and advances its course of knowledge and this will serve to maintain the dependency syndrome. The Indigenisation line of fit matrix shows that wealth created through this way is on a limited scale.

Unlimited Wealth Creation: High Level of Indigenisation which is supported by High Level product Beneficiation results in an unlimited wealth creation for the state economy. When indigenous people are fully engaged in the beneficiation activities, income derived from the activity is more than double. This is based on the assumption that indigenous people have a national interest, and income circulates in the country. Wealth is created when exports of primary products have been reduced and finished products are exported. The study recommendation is therefore based on the Unlimited Wealth Creation quadrant. The country is losing millions in the exports of raw material, and the indigenisation policy need to incorporate a 360 degree indigenisation program to create unlimited wealth for the nation.

The study also carries the recommendation to the Government of the United States to consider withdrawal of the Zimbabwe Democracy and Economic Recovery Act [S.494] [ZIDERA $]^{1}$ on both social and human rights basis to enable the economy of Zimbabwe tick and to promote survival of entrepreneurship in the country. 


\section{Further Study}

This paper recommends further study on the effects of sanctions to Zimbabwe on implementation of a comprehensive indigenisation program in the country.

\section{REFERENCES}

[1] Zimbabwe Democracy and Economic Recovery Act [S. 494] (ZIDERA)

[2] The Indigenisation and Economic Empowerment Act [Chapter 14:33] Parliament of Zimbabwe. Harare.

[3] The United Nations General Assembly resolution 1803[VX11] of [1962] principle of Permanent Sovereignty over Natural Resources (PSNR).United Nations.

[4] Chowa,T.[2013].An Analysis of Zimbabwe, 'Indigenisation and Economic Empowerment Program.(IEEP) as an Economic and Development Approach. Journal of Economics(1)2,2-18.

[5] Murombo,T.[2010].Law and the Indigenisation of Mineral Resources in Zimbabwean Equity for local communities? Available at http://reference.sabinet.co.za/sa publication article.co.za/sa

[6] Floyd,(1959:22) Floyd, BN (1959), "Changing Patterns of African Land Use in Southern Rhodesia", Rhodes-Livingstone Journal 25:20-39.

[7] Brinn, PJ [1987], Communal land physical resource inventory: Wedza district, Harare: Chemistry and Research Institute

[8] Gaidzanwa, Rudo [December 1981], Promised land: towards a land policy for Zimbabwe, Un published Master of Development Studies book, The Hague Institute of Social Studies

[9] New African Special Report [2013]. African Studies Review, 44[1] 28-66.

[10]Charter of the British South African Company (BSAC).Legal Resources Centre.

[11] The Companies Act No.47 of 1951.The Legal Resources Centre, Zimbabwe.

[12] The Factory Act No 20 of 1948 .The Legal Resources Centre, Zimbabwe

[13] The Public Health Act No.19 of 1924 [Chapter 328]: The Legal Resources Centre, Zimbabwe.

[14] The Urban Councils and Regional Town and Country Planning Act (Act 22 of 1976) The Legal Resources Centre, Zimbabwe.

[15] Food and Food standards Act No.25 of 1971 (Chapter 321)

[16] Second Hand and Goods Act No 25 of 1956 [Chapter 293] The Legal Resources Centre, Zimbabwe.

[17] The income tax Act No 5 of 1967 [Chapter 181] The Legal Resources Centre, Zimbabwe.
[18] The Land Apportionment [Act of 1930]. The Legal Resources Centre, Zimbabwe

[19] Wilson, J. 1990. Strategies of State Control of the Economy Nationalization and Indigenisation in Africa. Journal of Comparative Politics. 22 (4), 401-419.

[20] Dr Nathan Shamuyarira,(1998) Opening remarks at a student Seminar. Chinhoyi Technical Teachers College. (CTTC) Chinhoyi, Zimbabwe.

[21] Ministry of Youth, indigenisation and Empowerment, [2010] Draft handbook on Indigenisation and Empowerment in Zimbabwe

[22] Professor, Erica Irene, [2003] The International Labour Organization Indigenous and Tribal Peoples Convention No. 169/1989. The United Nations.

[23] Mbiti, JS (1992), African religions and philosophy, Second Edition, Heinemann

[24] Wright, CJH, [1983], Living as the people of God: The relevance of Old Testament ethics, UK: Intervarsity Press

[25] Masengwe, G. [2008] "Alienated Children of the Soil: The Challenge of the Land Crisis in Zimbabwe to Christian Eco-Theologies", Bulletin for Contextual Theology in Africa and Southern Africa, Pietermaritzburg (special double issue)

[26] Magure, B. [2012] Foreign investment, Black Economic Empowerment and Militarised Patronage Politics in Zimbabwe. Journal of Contemporary African Studies. (30)

[27] Thouvenot,S.[2014]. State Participation, Indigenisation and Economic Empowerment in Africa. Available at: http://www.tabj.co.za/features/april13features/state participation indigenisation and economic empowerment. Accessed 10/06/2014.

[28] Bell, [2010] Tsvangirai dismisses the Draconian indigenisation Bill Available:

http://www.swradiofrica.com.Accessed21/09.2014.

[29] Descombe, M.N (1998) Research Methods for Business Students, Prentice Hall $3^{\text {rd }}$ Edition

[30] Patton, M.[1994] Developmental Evaluation. Evaluation Practice, (15) 3,311-319.

[31] Saunders M. [2012] Research Methods for Business Students. Prentice Hall Publishers, New York

[32] Fungati, [2010] Ministry of Youth, indigenisation and Empowerment, [2010] Draft handbook on Indigenisation and Empowerment in Zimbabwe

[33] Stiglitz, J. E. 2007. What Is the Role of the State? Escaping the Resource Curse. New York: Columbia University Press.

[34] Zimbabwe Chamber of Mines. The indigenisation bill. Harare.

[35] Bein Freith, [2011] The New Africa Special Report, AN IC Publication.

[36] Makwiramiti, M.2011. In The Name of Economic Empowerment: A case for South Africa and Zimbabwe. Consultancy Africa Intelligence. Available at: http://www.consultancyafrica.com/index.php?option=com content\&view=article\&id 
[37] Friedman,D.P [2002] The International Oil Industry: An Interdisciplinary A Cost- Benefit Analysis of Norway's Statoil. Working Paper in Economics. Cambridge

[38] Raul Prebisch Dependency Theory developed in the 1950s.Globalisation .United Nations.

[39] Bauer, [2015], Globalisation. AN IC Publication.

[40] Mbeki, M [2011]. Advocates for change: How to overcome Africa's challenges.AN IC Publication.

[41] Manwere, L.[2013] Black Economic Empowerment -A Lawful Initiative to Obtain Equality AN IC Publications

[42] Roy, [1997] Imperialists and Globalisation and Labour. Website. http.www.Revolunarydemocracy.org

[43] Mbeki.[2012 ] Resource management in Africa.AN IC
Publication.

[44] Oslavalvo,[1969] Good enough governance revisited. Development Policy Review. [22) 1,

[45] Mupepereki, [2016], Zimbabwe Open University International Conference paper, June International Conference, 2016.Z.O.U.

[46] Norberg, J. [2003] The benefits of globalisation. A speech to the Frontier centre. Winniperg, 2003.

[47] Kirpalani, V.H., \& Macintosh, N.B. [2012], "International marketing effectiveness of technology-oriented small firms," Journal of International Business Studies, Winter: 81-90.

[48] Mabwa,[2008] The Welfare and Implications of Privatisation: Perspectiv: Ashgate Publishing Ltd. 